17 *Corresponding author: PhD María Inés Isla

18 INBIOFIV- CONICET

19 Universidad Nacional de Tucumán

20 San Lorenzo 1469

214000 - San Miguel de Tucumán. ARGENTINA Miguel de Tucumán, Tucumán, Argentina. Tucumán, Argentina. Casilla 170, Antofagasta, 1240000, Chile.

Telephone: $(+54) 3814203062$

\section{rheumatic and anti-inflammatory}

Leal, M. $^{\mathrm{a}}$, Zampini, I.C. ${ }^{\mathrm{a}, \mathrm{b}}$, Mercado, M.I. ${ }^{\mathrm{b}}$, Moreno, M.A. ${ }^{\mathrm{a}}$, Simirgiotis, M.J. $^{\mathrm{c}}$, Bórquez, J. ${ }^{\text {, }}$, Ponessa, G.I. ${ }^{\mathrm{b}}$, Isla, M.I. ${ }^{\mathrm{a}, b^{*}}$

Laboratorio de Investigación de Productos Naturales (LIPRON), Instituto de Bioprospección y Fisiología Vegetal INBIOFIV-CONICET), Facultad de Ciencias Naturales e IML, Universidad Nacional de Tucumán, San Lorenzo 1469, San

bInstituto de Morfología Vegetal. Área Botánica. Fundación Miguel Lillo, Miguel Lillo 251, San Miguel de Tucumán,

'Instituto de Farmacia, Universidad Austral de Chile, Campus Isla Teja, Valdivia, 5090000, Chile.

${ }^{\mathrm{d}}$ Laboratorio de Productos Naturales, Departamento de Química, Facultad de Ciencias Básicas, Universidad de Antofagasta,

E-mail: misla@tucbbs.com.ar; misla@csnat.unt.edu.ar 
Abstract

Ethnopharmacological relevance: Flourensia fiebrigii is a plant used in traditional medicine in the Argentine Calchaquí Valley as purgative, expectorant, anti-rheumatic and anti-inflammatory.

Aim of the study: The aim of this study was to analyze the macroscopic and microscopic characteristics of $F$. fiebrigii leaf and stem, the phytochemical composition of leaves ethanolic extracts and to validate its traditional use as anti-rheumatic and anti-inflammatory.

Materials and methods: The macroscopic and microscopic description of $F$. fiebrigii leaf and stem was carried out. Two extracts (immersions and tinctures) from leaves were obtained. The phytochemical analysis and UHPLC-OT-MS metabolome fingerprinting of both extracts were performed. The anti-rheumatic and anti-inflammatory activities of both extracts were determined using enzymatic inhibition assays of xanthine-oxidase (XOD), secretory phospholipase A2 (sPLA2) and lipoxygenase (LOX).

Results: The macroscopic and micrographic characters of F. fiebrigii were described to allow the botanical characterization of the plant species. The leaves extracts showed a high level of phenolic compounds with similar chromatographic patterns. Forty-five compounds were identified based on UHPLC-OT-MS including several sesquiterpenes, chalcones, flavonoids, isoflavonoids, a lignan and phenylpropanoids phenolic acids that have been identified for the first time in this plant species. F. fiebrigii extracts were able to inhibit the XOD activity and, consequently, the formation of uric acid and reactive oxygen species, primary cause of diseases, such as gouty arthritis ( $\mathrm{IC}_{50}$ values of 1.10-2.12 $\mu \mathrm{g} / \mathrm{mL}$ ). Pro-inflammatory enzymes like sPLA2 and LOX were also inhibited by $F$. fiebrigii extracts ( $\mathrm{IC}_{50}$ values of $22.00-2.20 \mu \mathrm{g} / \mathrm{mL}$ ) decreasing the production of inflammation mediators.

Conclusions: The present work validates the traditional medicinal use of $F$. fiebrigii as anti-rheumatic and anti-inflammatory through the use of enzymatic assays. The presence of several chemical compounds with demonstrated anti-rheumatic and antiinflammatory properties also supports the bioactivity of the F. fiebrigii.

Keywords: Flourensia fiebrigii; Argentine medicinal plant; tincture; ethanolic immersions; anti-rheumatic; antiinflammatory 
55 Flourensia fiebrigii S. F. Blake (Family Asteraceae, Tribu Heliantheae, Subtribe Enceliinae) is a glutinous shrub (Fig. 1) known 56 as chilca, maravilla, maravilla del campo, engordadora, incienso (Femenía 2009), viscol (Dillon 1984; Calo and Pereyra-

57 Domingorena, 2013), and biscol (Ospina et al., 2018). Both the distribution and habitat are in the mountains of north-western Argentina (Catamarca, Jujuy, La Rioja, Salta, and Tucumán) and southern Bolivia (Potosi); in fact, it has been found growing in rocky and sandy soils between 1200 and 4000 meters above sea level (m.a.s.l.) (Ospina et al., 2018). In popular medicine, aerial parts are used to alleviate symptoms of relieve various ailments and diseases as a purgative, expectorant, anti-rheumatic and antiinflammatory; in addition, they are used in incense sticks, and also as deodorant air freshener, dyeing agent, fuel or fodder et al., 2019).

The phytochemical characterization of the ethyl ether extract in the aerial parts of $F$. fiebrigii yielded three prenylflavonoids, namely, (2S)-8-(3"'-methylbut-2"'-enyl)-7,3',4'-trihydroxyflavanone, (2S)-8-(3"'-methyl-4"'-hydroxy-but-2"'-enyl)-7,3',4'trihydroxy flavanone and (2S)-8-(3"'-methyl-4'-hydroxy-but-2"'-enyl)-5,3',4'-trihydroxy-7-methoxyflavanone (Uriburu et al.,

67 2007, Reyes et al., 2013), as well as tremetone, 6-methoxytremetone, 8-prenyleriodictyol, 2-isopropenyl-3-oxyangeloyl-5acetyl-cis-2,3-dihydrobenzofuran and 5,3-dihydroxyisobavachin-7-O methyl ether (Uriburu et al., 2007). The presence of the phytotoxic sesquiterpene (-)-hamanasic acid A (-) HAA; 7-carboxy-8-hydroxy-1(2), 12(13)-dien-bisabolene was also reported by F. fiebrigii (López et al., 2014). Glycine betaine was also detected in F. fiebrigii and its content was regulated by UV-B (Piazza et al., 2014). Organic extracts of F. fiebrigii showed activity against mature biofilm of two pathogenic bacteria and low toxicity to freshwater snail species Biomphalaria peregrina (Verni et al., 2011). The F. fiebrigii extracts also showed phytotoxic effect on lettuce seed (López et al., 2014). The aim of the present study was to analyze both macroscopic and microscopic characteristics of aerial parts of $F$. fiebriigi and the chemical composition of leaf ethanolic extracts and to validate its traditional use as anti-rheumatic and anti-inflammatory. 


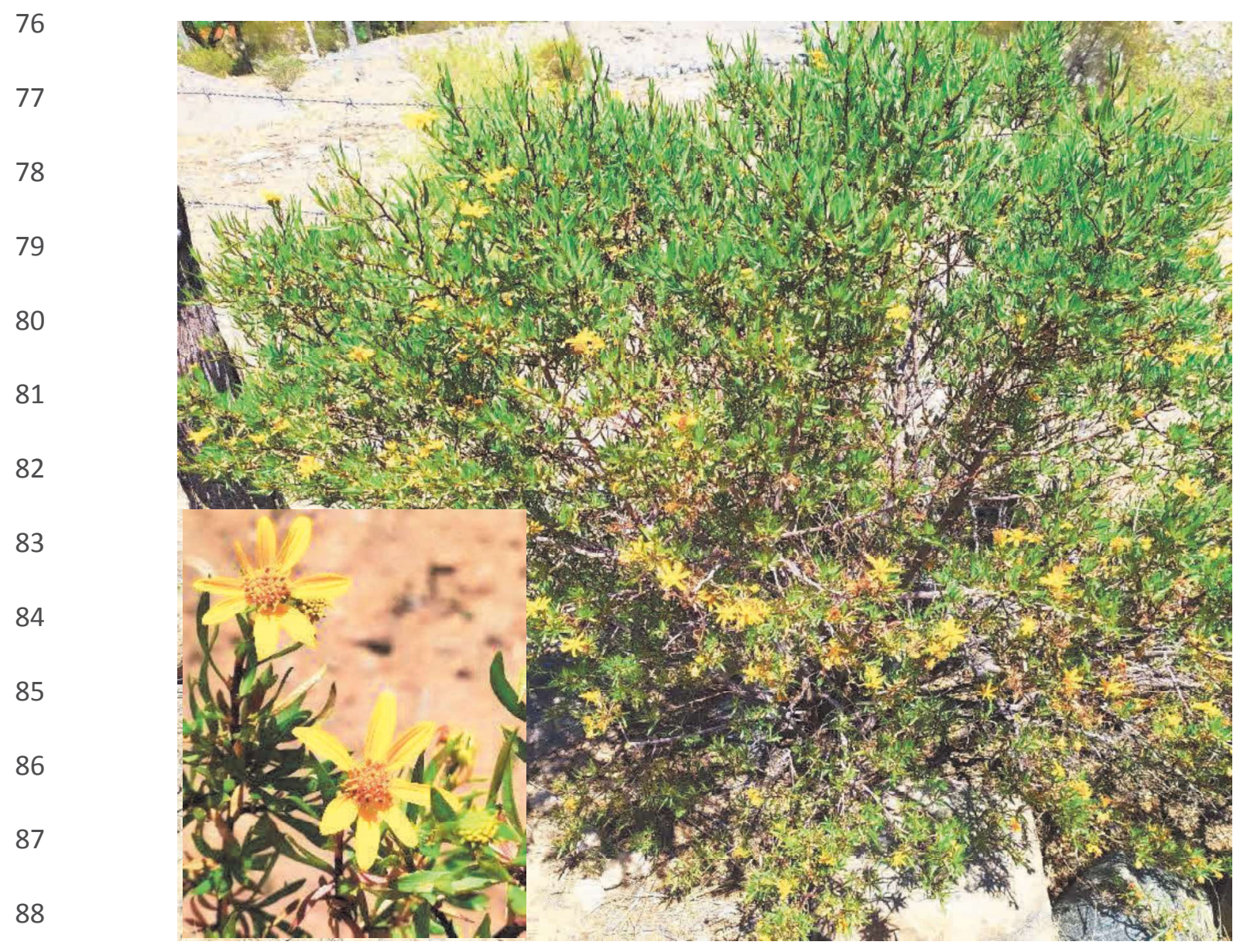

89 Fig. 1. Photograph of Flourensia fiebrigii, taken in Amaicha del Valle, Tucumán, Argentina by Mariana Leal, in January, 2019

\section{Materials and methods}

\subsection{Plant material collection}

Aerial parts from six individual plants of Flourensia fiebrigii S. F. Blake (www.theplantlist.org) were collected in January, at

Amaicha del Valle, Tafí del Valle, Tucumán (1500 m.a.s.1.). Voucher specimens of each collection were deposited at the

Herbarium of Fundación Miguel Lillo (LIL), Tucumán, Argentina (voucher number 707923/LIL).

97

For histological purposes, 5 specimens were selected. Stem segments of the first internode from the apex, 6 leaf primordia and 6 mature full expanded leaves (fourth or fifth leaf from the apex), were sampled. Half of the samples were fixed in FAA 
(formalin, acetic acid, 50\% ethanol, 5:5:90 v/v/v) and stored for one week after processing. The other half were used immediately or dried at room temperature for histochemical tests.

For anatomical characterization, sections of the stem and mid-region of the leaves (3-4 mm²), previously fixed in FAA, were placed between two plates of dental wax and sectioned. Sections of 15-20 $\mu \mathrm{m}$ were obtained with a rotation microtome MICROM HM 315, cleared with sodium hypochlorite (50\% commercial bleach) and washed with distilled water; then, they were stained with astra blue safranin and mounted in 50\% glycerol (Zarlavsky, 2014). Whole leaves of both primordial and full-expanded leaves were diaphonized according to Dizeo de Strittmater (1973) and stained with cresyl violet $1 \%$ in distilled water. For the description of the foliar venation, the terminology of Hickey $(1974,1979)$ and Ellis et al. (2009) was used. Stomaton types were described according to Dilcher (1974). For light microscopy (LM), sections were visualized with a Zeiss Axiolab optic microscope equipped with a polarized light filter and a Zeiss Axiocam ERc 5s digital camera. Tissue measurements were made by using Axio Vision software version 4.8.2 (Carl Zeiss Ltd, Herts, UK), n = 40. Statistical summary measures were calculated by using the statistical package Infostat (version 1.1).

\section{Scanning electron microscopy}

For scanning electron microscopy (SEM), samples were fixed in glutaraldehyde phosphate $5 \%$ buffered with 0.1 M sodium cacodylate at $\mathrm{pH} 7$, and post-fixed in $1.5 \%$ osmium tetroxide buffered with $0.1 \mathrm{M}$ sodium cacodylate at $\mathrm{pH}$ 7.2. Primordia and mature leaf segments were dehydrated in a graded acetone solutions series, submitted to a critical point drying by using $\mathrm{CO}_{2}$ and coated with gold (Fine Coat Ion Sputter JEOL JFC-1100). SEM of gold-coated samples was performed by using a ZEISS SUPRA-55 VP field emission scanning electron microscope at Centro Investigación y Servicios de Microscopía Electrónica (CISME), CONICET-UNT.

\subsection{Phytochemical analysis}

\subsubsection{Extracts preparation}

Immersions: F. fiebrigii leaves were dried in a forced air stove and then extracted by immersions in $60^{\circ}$ ethanol $(1: 10 ; \mathrm{W}: \mathrm{V})$ for $60 \mathrm{~s}$. The extract obtained was evaporated to dryness in a rotatory evaporator (below $50{ }^{\circ} \mathrm{C}$ ); the residue was dissolved in absolute ethanol (fraction A) and then, the insoluble portion was dissolved in distilled water (fraction B). 
Tincture: F. fiebrigii leaves were dried in a forced air stove and then ground to fine powder. Leaf powder was extracted by maceration in $80^{\circ}$ ethanol $(1: 10 ; \mathrm{W}: \mathrm{V})$ for $1 \mathrm{~h}$ with ultrasound application in cycles of 10 minutes. The extracts were filtered, taken to dryness under reduced pressure and lyophilized to obtain the dry extracts (extract C), which were placed in oxygen barrier bags and vacuum-packed until used (Multivac, D-8941, Germany).

\subsubsection{Total phenolic compounds and flavonoid quantification}

The extracts were standardized by the determination of total phenolic compound content by using Folin-Ciocalteu reagent (Singleton et al., 1999). Results were expressed as $\mu$ g of gallic acid equivalents (GAE) per mL ( $\mu$ g GAE/mL). Total flavonoids were estimated by using the method of Woisky and Salatino (1998). Results were expressed as $\mu$ g of quercetin equivalents (QE) per mL ( $\mu \mathrm{g} \mathrm{QE} / \mathrm{mL})$.

\subsubsection{Thin layer chromatography}

An aliquot of extract $(15 \mu \mathrm{g}$ GAE) was spotted onto a TLC plate $(8 \mathrm{~cm} \times 6 \mathrm{~cm})$ covered with silica gel (Merck F254). The TLC plate was developed in mobile phase (toluene:acetone:chloroform; 4.5:3.5:2.5). After drying, the plates were observed under UV light at $365 \mathrm{~nm}$ before and after development with Neu's reagent.

\subsubsection{Chemical composition determination by UHPLC-PDA-MS}

A Thermo Ultimate 3000 UHPLC system connected to a Thermo Q exactive focus was used in this study to allow a rapid separation. Photodiode (PDA) detection, high flow rates $(0.8 \mathrm{~mL}$ per $\mathrm{min})$ and zero dead volume with viper technology; effective negative electrospray ionization of the improved heated electrospray probe (HESI II) was used. As a result, ultrahigh resolving power performance with combined selectivity of a quadrupole and the orbital trap (70,000 FWHM at m/z 200), as well as the outstanding diagnostic power of a high-resolution collision (HCD) cell was achieved. For the analysis, 10 mg of the extract was dissolved in $2 \mathrm{~mL}$ of methanol, filtered (PTFE filter, 200 microns) and $15 \mu \mathrm{L}$ was injected in the instrument, with all specifications set as previously reported (Simirgiotis et al., 2016).

Liquid chromatography was performed by using a C-18 column (HPLC-Acclaim, $2.5 \mu \mathrm{m}, 150 \mathrm{~mm} \times 4.6 \mathrm{~mm}$ ID, Thermo, Bremen, Germany) operated at $25^{\circ} \mathrm{C}$. The detection wavelengths were $330,254,280$, and 354 nm, and photodiode array was recorded between 800-200 nm for UV characterization. Mobile phases were $1 \%$ formic aqueous solution (A) and acetonitrile (B). The gradient program (time in min, \% B) was: $0.00 \mathrm{~min}, 3 \% \mathrm{~B} ; 5.00 \mathrm{~min}, 3 \% \mathrm{~B} ; 10.00 \mathrm{~min} ., 20 \% \mathrm{~B} ; 15.00 \mathrm{~min}, 20 \% \mathrm{~B}$; $20.00 \mathrm{~min}, 45 \% \mathrm{~B} ; 25.00 \mathrm{~min}, 65 \% \mathrm{~B} ; 35.00 \mathrm{~min}, 3 \% \mathrm{~B}$ and $15 \mathrm{~min}$ for column equilibration before each injection. The flow 
rate was $0.8 \mathrm{~mL} / \mathrm{min}$, and the injection volume was $15 \mu \mathrm{L}$. The HESI II and Orbitrap spectrometer parameters were optimized as previously reported (Simirgiotis et al., 2016).

\subsection{Anti-inflammatory activity}

\subsubsection{Xanthine oxidase assay}

The effect of $F$. fiebrigii extracts on the activity of XOD $(0.1 \mathrm{U} / \mathrm{mL})$ was determined spectrophotometrically by measuring the synthesis of uric acid from hypoxanthine $(1 \mathrm{mM})$ at $290 \mathrm{~nm}$, in accordance with the technique described by Pérez et al. (2018). Indomethacin (20-100 $\mu \mathrm{g} / \mathrm{mL})$, acetylsalicylic acid (2-40 $\mu \mathrm{g} / \mathrm{mL})$ and allopurinol (2-100 $\mu \mathrm{g} / \mathrm{mL})$ were used as positive controls.

\subsubsection{Inhibition of lipoxygenase}

LOX activity was determined according to Torres-Carro et al. (2017). For this assay, soybean 1-LOX (948 U/mL) was exposed to different concentrations of the extracts ( 1 to $100 \mu \mathrm{g} \mathrm{DW} / \mathrm{mL})$ or vehicle $(0.1 \%$ DMSO final concentration) and its substrate, linoleic acid $(50 \mu \mathrm{M})$. Naproxen $(2-20 \mu \mathrm{g} / \mathrm{mL})$ was used as reference compounds. The inhibitory capacity was determined by calculating the percentage of inhibition of the hydroperoxide production at $234 \mathrm{~nm}$ for 5 min of incubation. The enzymatic reaction kinetics was followed by measuring product formation every $1 \mathrm{~min}$. The concentration that inhibits $50 \%$ of LOX's activity $\left(\mathrm{IC}_{50}\right)$ was determined by regression analysis with a dose-response curve.

\subsubsection{Inhibition of secretory Phospholipase A2}

The inhibitory activity of F. fiebrigii extracts on sPLA2 was determined according to Torres Carro et al. (2017). Different concentrations of extracts ( 1 to $100 \mu \mathrm{g} \mathrm{DW} / \mathrm{mL}$ ) or vehicle $(0.1 \%$ DMSO final concentration) were included in the reaction mixture with 1,2-Diheptanoilthio-glycerophosphocholine (1,2-dHGPC) as substrates and sPLA2 (0.04 $\mu \mathrm{g} / \mathrm{mL})$. Acetyl salicylic acid (up to a maximum concentration of $200 \mu \mathrm{g} / \mathrm{mL}$ ) was used as a standard drug. The reaction kinetics was determined at 414 $\mathrm{nm}$ every $2 \mathrm{~min}$ for $20 \mathrm{~min}$.

\subsection{Statistical analysis}

All assays were performed at least three times with three different sample preparations. Each experimental value was expressed as the mean \pm standard deviation (SD). The scientific statistic software InfoStat (Student Version, 2011) was used to evaluate the significance of differences between groups. Comparisons between groups were made by using a Tukey’s test. 


\section{Results}

Native people from the highlands in northwestern Argentina use "chilca or viscol" extracts to help cure inflammatory processes; consequently, the present work analyzes the chemical composition and anti-inflammatory activity of extracts obtained from aerial parts of this plant. The botanical identity was established by taxonomic determination and micrographic studies.

\subsection{Leaf morphology and anatomy}

Flourensia fiebrigii presented alternate, shortly petiolated, coriaceous, microphyll, yellow-green, leaves which are aromatic and glutinous-sticky to the touch. Petiole is $1.5-6 \mathrm{~mm}$ length, slightly sheeted at the base. The blade shape may range from linear lanceolate to oblong-lanceolated, medially symmetrical, $1-5 \mathrm{~cm}$ length by $2-5(-10) \mathrm{mm}$ latitude; it may be attenuated asymmetrical at the base; its apex is acute, with the entire margin displaying non-glandular hairs and glandular trichomes on both epidermal surfaces (Fig. 2A-G). These results are in accordance with those described for the species in the Argentinean Flora by Ariza Espinar \& Ospina, (2015), and Delbon et al. (2012); they describe F. hirta S. F. Blake recently synonymized with F. fiebrigii by Ospina et al. (2018). Glandular trichomes and glutinous deposits are much more evident in leaf primordial and basal segment of the blade of mature leaves (Fig. 2A-E). The slightly different quantitative differences observed regarding the values reported by other authors may be due to a large phenotype plasticity as suggested by Ospina et al. (2018).

The venation pattern presented a primary venation pinnate (Fig. 2I), with a primary vein massive with straight course. Major secondary veins were excurrent, alternate to sub opposite, diverging in acute angles from the primary vein, forming a eucamptodromous framework with irregular spacing gradually increasing toward the apex. Epimedial and intercostal tertiary vein was generally reticulated with inconsistent vein angles, anastomose with other tertiary or secondary veins to form an irregular polygonal net; it is infrequently per current. Exterior tertiary veins form loops, and quaternary veins constitute the minor order, with a reticulated vein fabric forming areoles, sometimes with one sometimes branched freely ending veinlet or none at all (Fig. 2 H-I). 

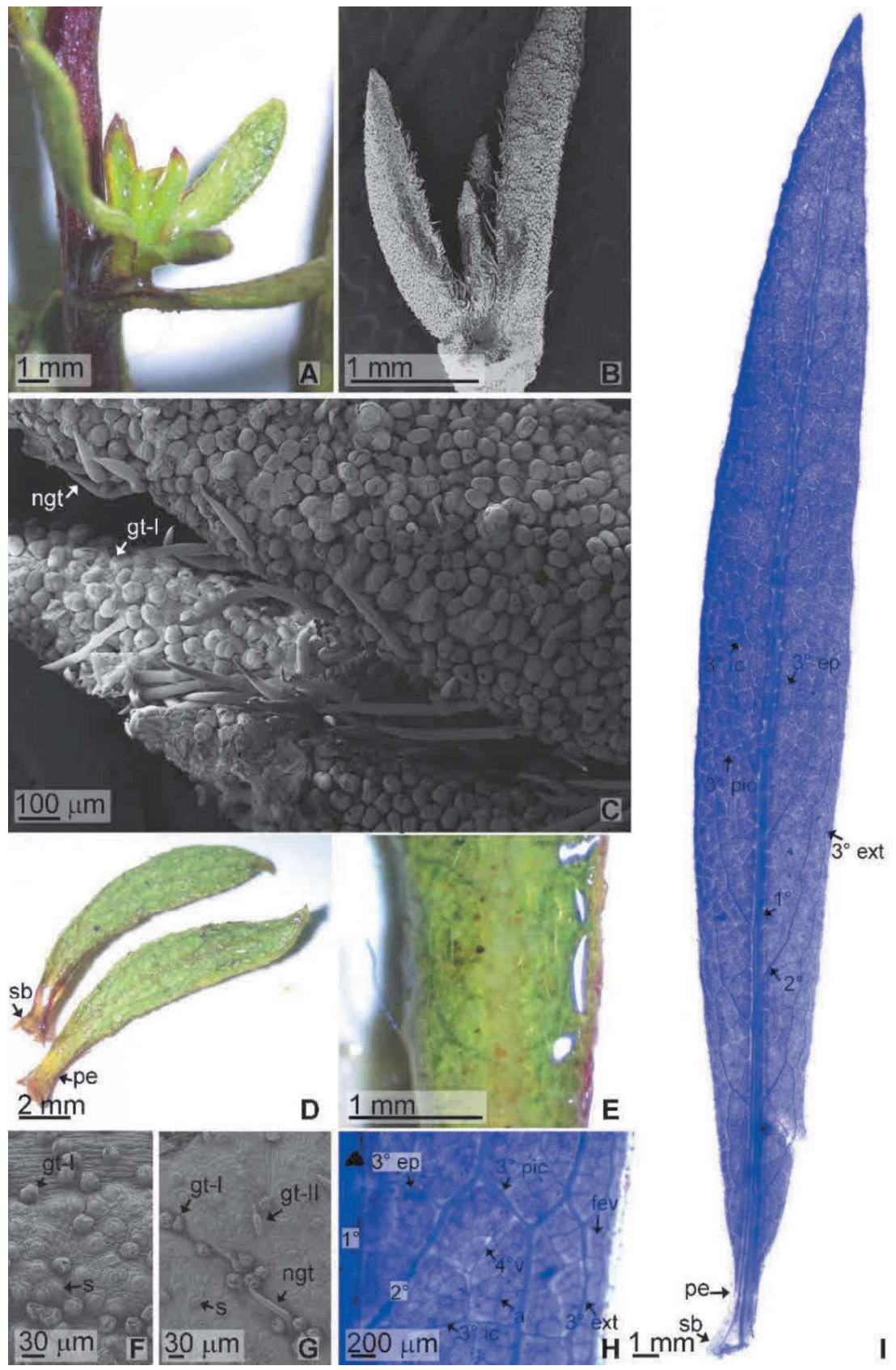

204 Fig. 2. Flourensia fiebrigii. A-B. Axillary bud and leaf primordia. A- Glutinous appearance to magnifying glass. B-C. MEB revealing high density of glandular trichomes (gt). D. Mature leaves, general aspect. E. Detail of basal segment of the blade of mature leaves, showing glutinous deposits. F-G. MEB adaxial and abaxial epidermis of mature leaves respectively. E-F. Venation pattern. References: $1^{\circ}$, primary vein; $2^{\circ}$, secondary vein; $3^{\circ}$ ep, epimedial tertiary vein; $3^{\circ}$ ext, exterior tertiary vein; $3^{\circ}$ ic, intercostal; $3^{\circ}$ pic, percurrent intercostal tertiary vein; $4^{\circ}$, quaternary vein; a, areole; fev, freely ending veinlet; gt-I, glandular trichome type I; gt-II, glandular trichome type II; ngt, non-glandular trichome; pe, petiole; s, stoma; sb, sheeter base.

210

211 
At first sight, mature leaves were amphistomatic with smooth to slightly striated cuticle; anomocytic stomata, $39.85 \pm 5.15 \mu \mathrm{m}$ long. by $30.82 \pm 3.05 \mu \mathrm{m}$ lat. and $38.14 \pm 4.32 \mu \mathrm{m}$ long. by $27.01 \pm 3.77 \mu \mathrm{m}$ lat. for the adaxial and abaxial surface respectively, slightly raised above the level of the epidermal cells and at a density of $72.95 \pm 12.55$ and $77.90 \pm 13.95 / \mathrm{mm}^{2}$ for the adaxial and abaxial epidermis respectively. Both epidermal surfaces presented polygonal epidermal cells with slightly curved anticlinal walls (Fig. 3A-B). Pluricelular uniseriated non-glandular trichomes (ngt), antrorse toward the apex were observed at the margin and occasionally on the leaf blade or the mayor veins at the adaxial or abaxial surface. The ngt, presented $328.74 \pm 47.47 \mu \mathrm{m}$ in length and 3-4 short cells with the basal one sometimes bulbous. Two types of glandular trichomes were also observed; they were capitate glandular trichomes type I (gt-I), pluricellular biseriated with 2 pairs of basal cells and 3-4 pairs of head cells with an expanded cuticle around the apical pair, not always evident. In this case, the subcuticular space is filled with the secretion product. gt-I were observed abundantly in both epidermal surfaces, especially over the veins (Fig. 2F-G, 3D-E). There were also glandular trichomes type II (gt-II), pluricellular uniseriated with 4-5 short basal cells and a more or less elongated apical cell tick walled with a rounded end, scarce on both epidermal surfaces (Fig. 2G, 3F). Similarly, Delbon et al. (2007, 2012) described ngt and gt-II for F. niederleinii S. F. Blake, F. thurifera (Molina) D.C. and F. tortuosa Griseb., which currently contains the formerly F. campestris Griseb., F. leptopoda S. F. Blake and F. oolepis S.F. Blake. However, the trichomes described by these authors as non-glandular filiform are defined as gt-I in the present work.

Glandular trichomes type I are a common feature in many Asteraceae (Metcalfe and Chalk, 1950) and Flourensia sp. (Delbon et al, 2007, 2012). In glandular trichomes, formation and maturity precede the development of the plant organ on which they are located, terminating their secretory activity before the onset of leaf expansion (Göpfert et al, 2005; Mercado et al, 2012). This fact can explain the higher trichomes density exhibited by F. fiebrigii buds and foliar primordia, and the abundant deposits of secreted materials (Fig. 2 A-C) in comparison to fully-expanded leaves, in which the secretions are mostly accumulated at the base of the petiole after the expansion of the leaf blade (Fig. 2D-E). As stated by Delbon et al. (2012), glandular trichomes seem to be a common trait shared by many species of the genus Flourensia, whose structures may allow an adaptive defense against herbivores and other biotic and abiotic factors.

In transversal section Flourensia fiebrigii showed isolateral leaves with homogeneous (7-8 layers) palisade mesophyll interrupted by collateral vascular bundles (Fig. 3G). Thick cuticle, uniseriate epidermis, stomata slightly raised above the epidermal cells with substomatic chambers and guard cells with outer cuticular ledge was shown (Fig. 3H). Minor collateral vascular bundles 
were embedded in the mesophyll and enclosed by a sheath alternating thick-walled parenchyma cells and/or fibers, with the sheath sometimes presenting parenchyma or lignified extensions towards the adaxial or the adaxial and abaxial epidermal surfaces (Fig. 3G). The margin sometimes showed 1-4 layer of sub epidermal laminar collenchyma reinforcements (Fig. 3I). Schizogenous ducts with unistrate secretory epithelium were observed, toward the xylem and /or phloem poles, being a part of the vascular bundle sheaths and sheath prolongations, surrounded by thick-walled parenchyma cells and fibers (Fig. 3I-J).

The midrib shows a biconvex shape with uniseriate epidermis, with 8-10 layers of angular to laminar sub epidermal collenchyma on the adaxial and abaxial sides. The ground parenchyma is made up of thick-walled parenchyma cells, and the vascular system exhibits a single collateral vascular bundle, surrounded by a parenchymatous sheath reinforced by incomplete sclerenchyma cups toward the xylem and phloem poles (Fig. 3G). Embedded into the ground parenchyma, 2-5 schizogenous ducts with unistrate secretory epithelium were observed generally toward the phloem poles but also occasionally toward the xylem pole.

The petiole in transection presented plain-convex shape with epidermis showing the same characteristics previously described for the leaf blade and 1-5 layer of laminar sub epidermal collenchyma. The vascular system has an interrupted arch shape with 3-5 collateral bundles accompanied toward the phloem poles by 2-5 schizogenous ducts immersed in the petiole ground tissues. The sheeter base of the petiole presented a winged shape with uniseriated epidermis, 1-3 layers of sub epidermal laminar collenchyma, homogeneous ground parenchyma formed by rounded parenchyma cells, and three collateral vascular bundles, one with central position and one on each margin both accompanied by 1-2 schizogenous ducts toward the phloem pole. 

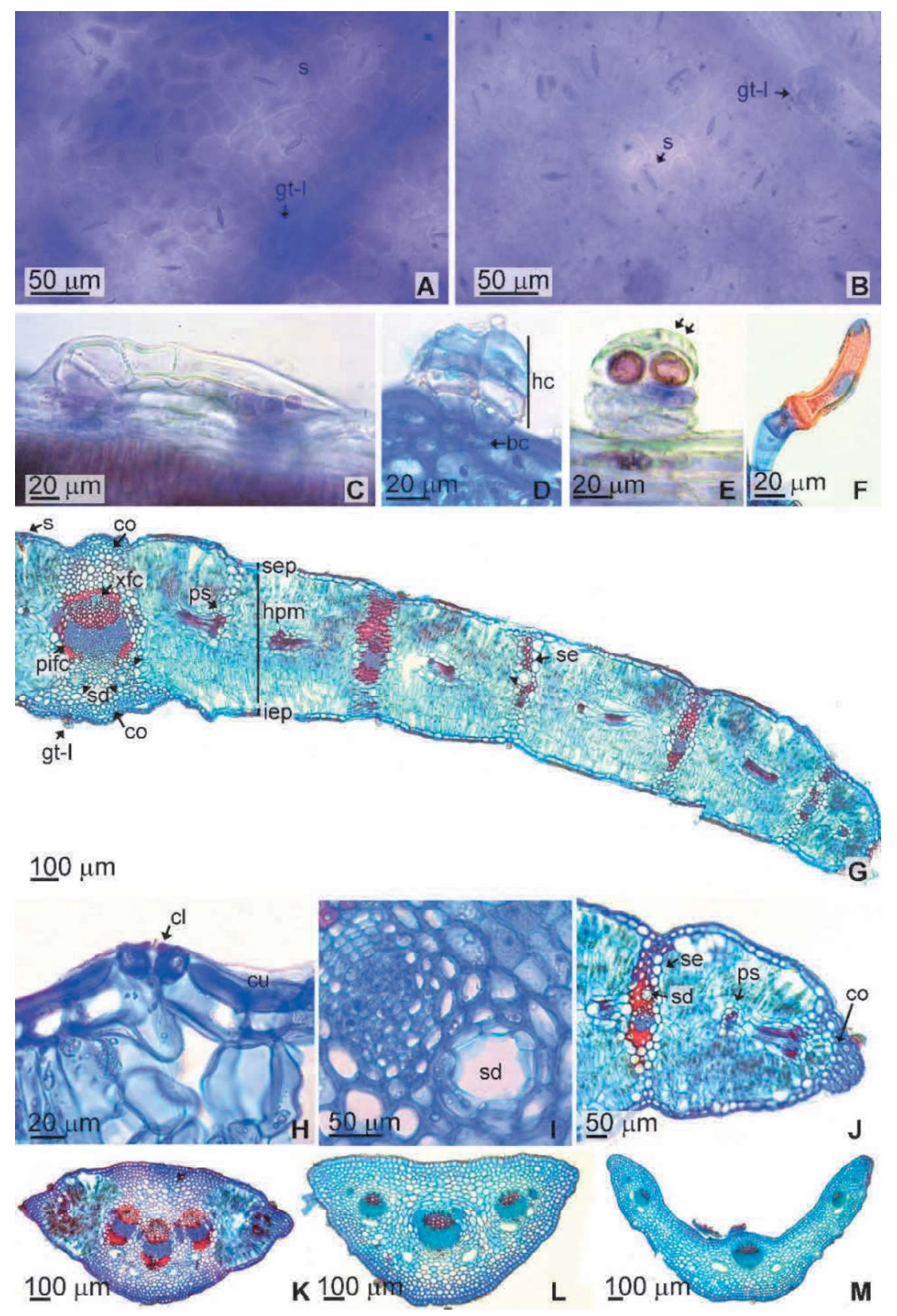

Fig. 3. Flourensia fiebrigii. A-B. Adaxial and abaxial epidermis respectively. C. Non-glandular trichome. D-E. Glandular trichome type I, arrows indicate expanded cuticle. F. Glandular trichome type II. G. Leaf transversal section. H. Stoma transversal section. I. Secretory duct. J. Leaf margin. K. Petiole transversal section in region where the lamina base becomes attenuated. L. Petiole transection. M. Petiole sheeter base transection. inferior epidermis; pifc; phloem incomplete fiber cup; ps, parenchyma sheath; s, stoma; sd, secretory duct; se, sheath extensions; sep, superior epidermis; xfc, xylem 
In transversal section the stem presented circular shape and incipient secondary growth (Fig. 4A). The epidermis consists of a single layer of cells with gt-I (Fig. 4B) and ngt (Fig. 4A-C) like those described for the leaf. Two to three layers of earlydeveloped phellem could be seen, displaying lignin deposits in the external tangential walls, not well-defined felogen and 2-3 layers of phelloderm formed by cells with thick primary walls (Fig. 4A). 12-16 layers of thick-walled parenchyma cells with starch grains constitute the cortex and it is interrupted by secretory ducts identical to those described for the leaf. The vascular cylinder shows a typical eustele structure (Fig. 4A) with open collateral vascular bundles., perivascular collenchyma cups turning into to fibers toward the phloem poles (Fig. 4A). The pith parenchyma cells showed thick primary cell walls and starch grains (Fig. 4A).

This is the first time that the foliar architecture of $F$. fiebrigii has been depicted.

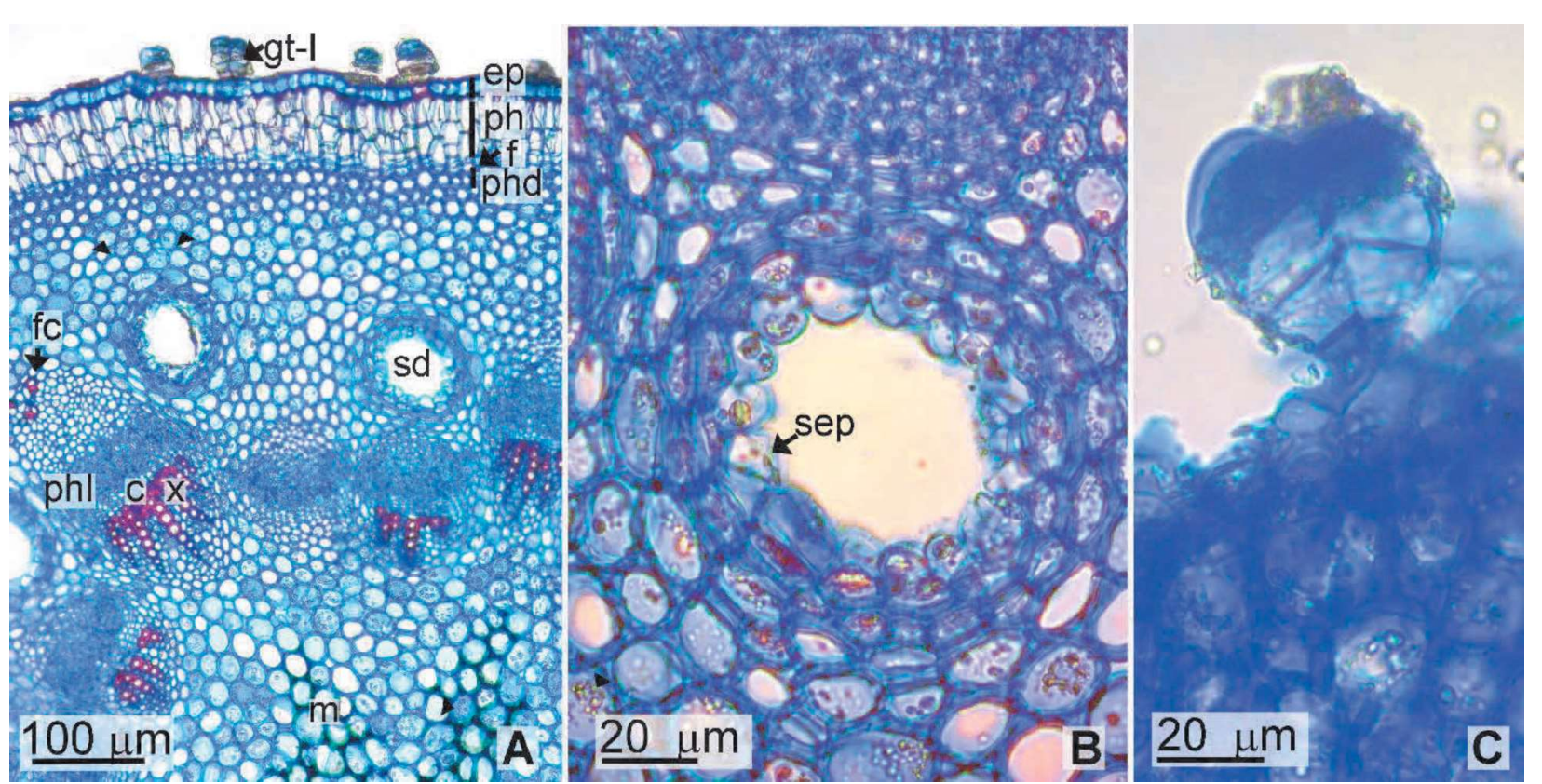

Fig. 4. Flourensia fiebrigii. A. Stem transversal section. B. Secretory duct. C. Glandular trichome type-I. References: arrow head, indicates starch grains in cortex and medulla cells.c, cambium; ep, epidermis; f, felogen; fc, fiber cup; ph, phellem; phd, phelloderm; phl; phloem; sd, secretory duct; sep, secretory epithelium; x, xylem.

\subsection{Phytochemical characterization of F. fiebrigii extracts}

The phytochemical composition of ethanolic and aqueous fractions of leaf immersions (A and B) and tincture (C) was determined. The extracts contained a high level of total phenolic compounds (TPC: $852 \pm 1.0 \mathrm{mg} \mathrm{GAE} / \mathrm{g}$ dry extract; $884.73 \pm$ 1.5 mg GAE/g dry extract and $947.82 \pm 1.2 \mathrm{mg} \mathrm{GAE} / \mathrm{g}$ dry extract in A, B and C, respectively), and flavonoid compounds (FC: 
$13.54 \pm 2.0 \mathrm{mg} \mathrm{QE} / \mathrm{g}$ dry extract; $15.52 \pm 1.0 \mathrm{mg}$ QE/g dry extract; $34.16 \pm 1.2 \mathrm{in} \mathrm{A,} \mathrm{B} \mathrm{and} \mathrm{C,} \mathrm{respectively).} \mathrm{The} \mathrm{extracts} \mathrm{yields}$ were 2.5 and $21 \mathrm{~g}$ dry extract/100 g plant material for ethanolic immersion and tincture, respectively.

Forty-five compounds were identified in the F. fiebrigii extracts, several organic acids, mainly phenylpropanoid acid derivatives, a lignan, chalcones, flavonoids, isoflavonoids, sesquiterpenes and erythritol derivatives (Fig. 5, Table 1). Saturated organic acids, such as quinic acid, diethyl tartrate, glaucarubinone and neosolaniol, were identified. Cinnamic acid derivatives such as chlorogenic acid and neochlorogenic acid $\left(\mathrm{C}_{17} \mathrm{H}_{17} \mathrm{O}_{9}{ }^{-}\right)$, gallic acid glucoside called bergenin $\left(\mathrm{C}_{14} \mathrm{H}_{15} \mathrm{O}_{9}{ }^{-}\right)$and $\mathrm{O}$-caffeoyl-xylose isomers $\left(\mathrm{C}_{14} \mathrm{H}_{15} \mathrm{O}_{8}{ }^{-}\right), 2,5$-dihydroxycinnamic acid $\left(\mathrm{C}_{9} \mathrm{H}_{7} \mathrm{O}_{4}{ }^{-}\right)$, 3,5-dicaffeoylquinic acid and 1,3-dicaffeoylquinic acid $\left(\mathrm{C}_{25} \mathrm{H}_{23} \mathrm{O}_{12}{ }^{-}\right)$, isomers, 1-caffeoyl-5-feruloylquinic acid, and 3-caffeoyl-5-feruloylquinic acid were also identified. Finally, schizandrin $\mathrm{B}\left(\mathrm{C}_{23} \mathrm{H}_{27} \mathrm{O}_{6}{ }^{-}\right)$, a dibenzocyclooctadiene lignan, a compound with demonstrated antiinflammatory and antioxidant activities (Shengban et al., 2019), was also identified in the extracts. Chlorogenic acid, bergenin, 2,5-dihydroxy-cinnamic acid, 1-O-caffeoyl-xylose, 3,5-dicaffeoylquinic acid, and diethyl tartrate were found only in ethanolic immersions (A) and the other cinnamic derivatives were also found in ethanolic immersions (A and B) and tincture (C).

Flavonoids such as laricitrin 3-O-glucoside $\left(\mathrm{C}_{22} \mathrm{H}_{21} \mathrm{O}_{13^{-}}\right)$, quercetin dimer $\left(\mathrm{C}_{30} \mathrm{H}_{20} \mathrm{O}_{14^{-}}\right)$, isorhamnetin $\left(\mathrm{C}_{16} \mathrm{H}_{11} \mathrm{O}_{7}^{-}\right)$, 8methoxyeriodyctiol $\left(\mathrm{C}_{16} \mathrm{H}_{13} \mathrm{O}_{7}^{-}\right)$, naringenin $\left(\mathrm{C}_{15} \mathrm{H}_{11} \mathrm{O}_{5}\right)$, 3-O-methylquercetin $\left(\mathrm{C}_{16} \mathrm{H}_{11} \mathrm{O}_{7}^{-}\right)$, methyl-isorhamnetin or 4',5' dimethyl quercetin $\left(\mathrm{C}_{17} \mathrm{H}_{13} \mathrm{O}_{7}^{-}\right)$, quercetin $\left(\mathrm{C}_{15} \mathrm{H}_{9} \mathrm{O}_{7}^{-}\right)$, rhamnetin $\left(\mathrm{C}_{16} \mathrm{H}_{11} \mathrm{O}_{7}^{-}\right)$, 3, 5' dimethyl quercetin $\left(\mathrm{C}_{17} \mathrm{H}_{13} \mathrm{O}_{7}^{-}\right)$, sakuranetin $\left(\mathrm{C}_{16} \mathrm{H}_{13} \mathrm{O}_{5}^{-}\right)$, 7-O-methyl quercetin $\left(\mathrm{C}_{16} \mathrm{H}_{11} \mathrm{O}_{7}{ }^{-}\right)$, and 2-hydroxy-naringenin $\left(\mathrm{C}_{15} \mathrm{H}_{11} \mathrm{O}_{6}{ }^{-}\right)$were identified in ethanolic immersion $(\mathrm{A}$ and $\mathrm{B})$ and tincture $(\mathrm{C})$.

Isoflavones, such as irigenin, a hydroxyisoflavone substituted by hydroxy groups, at positions 5, 7 and 3' and methoxy groups at positions 6, 4' and $5^{\prime}\left(\mathrm{C}_{18} \mathrm{H}_{15} \mathrm{O}_{8}{ }^{-}\right)$were identified. Recently, it has been suggested that these isoflavonoids possess not only antioxidative and anti-inflammatory activities, but also antitumor activities (Wang et al., 2017; Amin et al., 2016).

Three chalcones were identified, namely, naringenin chalcone $\left(\mathrm{C}_{15} \mathrm{H}_{11} \mathrm{O}_{5}^{-}\right)$, sakuranetin chalcone $\left(\mathrm{C}_{16} \mathrm{H}_{13} \mathrm{O}_{5}{ }^{-}\right)$, and $4,4-$ dimethoxychalcone $\left(\mathrm{C}_{17} \mathrm{H}_{15} \mathrm{O}_{3}^{-}\right)$. The former exhibits anti-inflammatory properties by inhibiting the production of proinflammatory cytokines in the interaction between adipocytes and macrophages. These compounds may be a useful phytochemical for suppressing the vicious cycle of chronic inflammation in obese adipose tissue, and improve obesity-related insulin resistance (Hirai et al., 2007). 
The sesquiterpenes carabrone and (-)-hamanasic acid A (HA) were only identified in F. fiebrigii tinctures, though not detected in ethanolic immersion fraction. Other authors reported the presence of HA for F. campestris and F. oolepis (Silva et al., 2015) and for F. fiebrigii (López et al., 2014) in chloroformic extracts. These compounds have proved to have phytotoxic and antibacterial activity (Verni et al, 2011).

Other compounds (peaks 36, 40 and 42) were identified as isomers of pentaerythritol ethoxylate $\left(\mathrm{C}_{13} \mathrm{H}_{27} \mathrm{O}_{8}^{-}\right)$. These compounds increased viscosity and thermal stability, and retarded drying time of fatty-acid based alkyd resins (Hadzich et al., 2020).

The presence of compounds (chalcones, isoflavones, lignans and flavonoids) with demonstrated anti-inflammatory activity in the F. fiebrigii extracts would indicate a potential anti-inflammatory activity thereof. To confirm such anti-inflammatory activity, it was decided to use internationally accepted enzyme models.

\subsection{Anti-inflammatory activity}

The increasing development of drugs is based on the discovery of new targets, usually enzymes, that are unique or overexpressed in a disease, and these enzymes are considered pharmacological targets (Holdgate et al., 2017; Pereira et al., 2020). The inhibitors are generally validated by using enzyme assays to quantify its inhibitory activity generally by IC 50 (half- maximal inhibitory concentration) values determination (Holdgate et al., 2017). It is for this reason that the anti-inflammatory and anti-rehumatic activity of $F$. fiebrigii extracts was analyzed on enzyme targets.

\subsubsection{Inhibitory activity on xanthine oxidase}

Xanthine-oxidase catalyzes the oxidation of hypoxanthine and xanthine to superoxide anion and uric acid in the purine nucleotide catabolism. Its re-oxidation involves molecular oxygen, which acts as electron acceptor, and during this reaction, superoxide radical and hydrogen peroxide are produced. Thus, the over activity of XOD leads to the deposition of uric acid in the susceptible tissues, a fact that triggers the inflammatory pathways with a concomitant release of reactive oxygen species (ROS). Persistent hyperuricemia is the primary cause of urate deposition diseases, such as gouty arthritis, gouty tophi, and renal damage. Therefore, in order to lower the serum uric acid level below the threshold, the xanthine oxidase inhibitor can block the biosynthesis of uric acid from purine in vivo. Although therapeutic agent allopurinol, a purine-based compound, has commonly been used for the treatment of hyperuricemia in clinic as XOD inhibitor, severe side effects of these traditional agents aroused safety concerns, including bone marrow depression, hematological, hepatic, renal and gastrointestinal toxicities, and allergic reactions (Wang et al., 2015). Febuxostat, a XOD inhibitor with a different, non-purine scaffold, has entered the market more recently and features 
an increased effectiveness in comparison to allopurinol, whose high dosage levels are known to make side-effects such as renal failure or Stephens-Johnson syndrome more likely (Garcia-Valladares et al., 2011). Therefore, it is necessary to find the efficient and less toxic XOD inhibitors for pharmaceutical applications. The excessive ROS production must also be stopped because oxidative stress-associated inflammation is a major cause for the precipitation of monosodium urate and subsequent tissue damage (Li et al., 2018).

The extracts of $F$. fiebrigii showed a high capacity to inhibit XOD activity (Table 2) with IC 50 values of 2.36 to $4.35 \mu \mathrm{g}$ GAE/mL. It is important to remark that the extracts were more active than allopurinol, a specific inhibitor of XOD (Table 2). Flavonoids, phenolic acids and their derivatives have been reported to have inhibitory effects on XOD (Gawlik-Dziki et al., 2017; Choi et al., 2019). Extracts B and C of F. fiebrigii were more active than extract A as XOD inhibitor. These results could indicate that not only flavonoids and chalcones present in A have anti-XOD activity but also phenylpropanoid acids present in extracts B and C. The planar structure and the $\mathrm{C} 2=\mathrm{C} 3$ double bonds of flavonoids were advantageous for binding to XOD. Both the hydroxylation on ring $\mathrm{B}$ and the substitution at $\mathrm{C} 3$ were unfavorable for XOD inhibition more profoundly than their XOD affinity. The methylation greatly reduced the inhibition but hardly affected the affinity. The bulky sugar substitutions of flavonoids decreased the inhibition and lowered the affinities to different degrees depending on the conjunction (Lin et al., 2015). Molecular docking studies suggested that critical XOD/inhibitor interactions involved $\pi-\pi$ interactions between the phenolic ring and Tyr914, hydrogen bonds between inhibitor hydroxyl groups and Glu802, and also hydrophobic interactions between the phenyl ring in the inhibitors and nonpolar residues located at the entrance of the binding site in XOD enzyme (Choi et al., 2019).

Based on the above analysis, F. fiebrigii might be helpful to reduce the serum uric acid level below the threshold by inhibiting the activity of XOD. These results would support, in part, the popular use of $F$. febrigii as anti-rheumatic agent.

\subsubsection{Inhibition of arachidonic acid pathway enzymes}

The arachidonic acid (AA) pathway is one of the most important processes involved in the inflammatory response. The first enzyme of AA pathway is secretory phospholipase A2 (sPLA2). In response to intracellular cytokines or to an increase of intracellular levels of calcium, sPLA2 releases AA from the plasmatic membrane, which is then oxidized by pro-inflammatory enzymes such as Cycloxygenase (COX) or Lipoxygenase (LOX) to produce eicosanoids, mediators of inflammatory processes. The F. fiebrigii extracts were able to suppress the inflammatory response, acting as inhibitor at two levels of AA pathway, 
namely, at level of sPLA2 and LOX. Table 2 displays the inhibition level of sPLA2 and LOX activities by F. fiebrigii extracts with $\mathrm{IC}_{50}$ values between 20.20 and $2.20 \mu \mathrm{g}$ GAE/mL. The inhibitory activity on LOX was higher than on sPLA2. But, in both cases, the inhibitory activity of extracts $\mathrm{B}$ and $\mathrm{C}$ was higher than that of extract A (Fig. 6) and higher than Acetyl salicylic acid and Naproxen, two commercial antiinflammatory medicines. The inhibitory activity of F. fiebrigii extracts on PLA2 and LOX could be attibuted to flavonols, such as quercetin and myricitin derivates, as well as naringenin (flavonone), present in these extracts (Kim et al., 2004). In general, studies on in vitro structure-activity relationships performed in biological models indicated that the striking structural features to inhibit these enzymes are similar to those of COX-2. These features are involved in important interactions and hydrogen bond formations with LOX and PLA2 active site (Kim et al., 2004; Mascayano et al., 2010; Catarino et al., 2016). Such interactions would be place with the following: the catechol group in ring-B, a catechol-like group in the A-ring, the 4-keto group, as well as in the unsaturated function between $\mathrm{C} 2$ and C3and the hydroxylations at C-5 and -7. It can be clearly seen that the presence of group 3-OH hampers the inhibitory activity of quercetin toward 5-LOX,, as compared to luteolin (Ribeiro et al., 2014),. This has not been supported by the studies of Vázquez-Agell et al. (2007) who have described this $\mathrm{OH}$ group as important for a stable binding of quercetin to LOX. Besides, chalcones with 3,4-dihydroxycinnamoyl structures, present in F. fiebrigii tissues have been reported to inhibit LOX and COX and to act as anti-allergic agents (Kim et al., 2004; Yadav et al., 2011). Consequently, naringenin and sakuranetin chalcones, detected in F. febrigii could also be responsible for anti-LOX activity. These results would support the use of $F$. febrigii as an anti-inflammatory agent.

\subsection{Conclusions}

The results obtained would indicate that $F$. fiebrigii extracts could be a good alternative therapy for the treatment of inflammatory processes, supporting its traditional use; however, in vivo tests are necessary to determine the effectiveness of their use. The chemical composition determined here has a direct relationship with the anti-inflammatory effectiveness demonstrated in specific enzymatic assays. Furthermore, the present work constitutes an original contribution to the knowledge of the macroscopic and microscopic characteristic of $F$. fiebrigii to assure its botanical identity. 


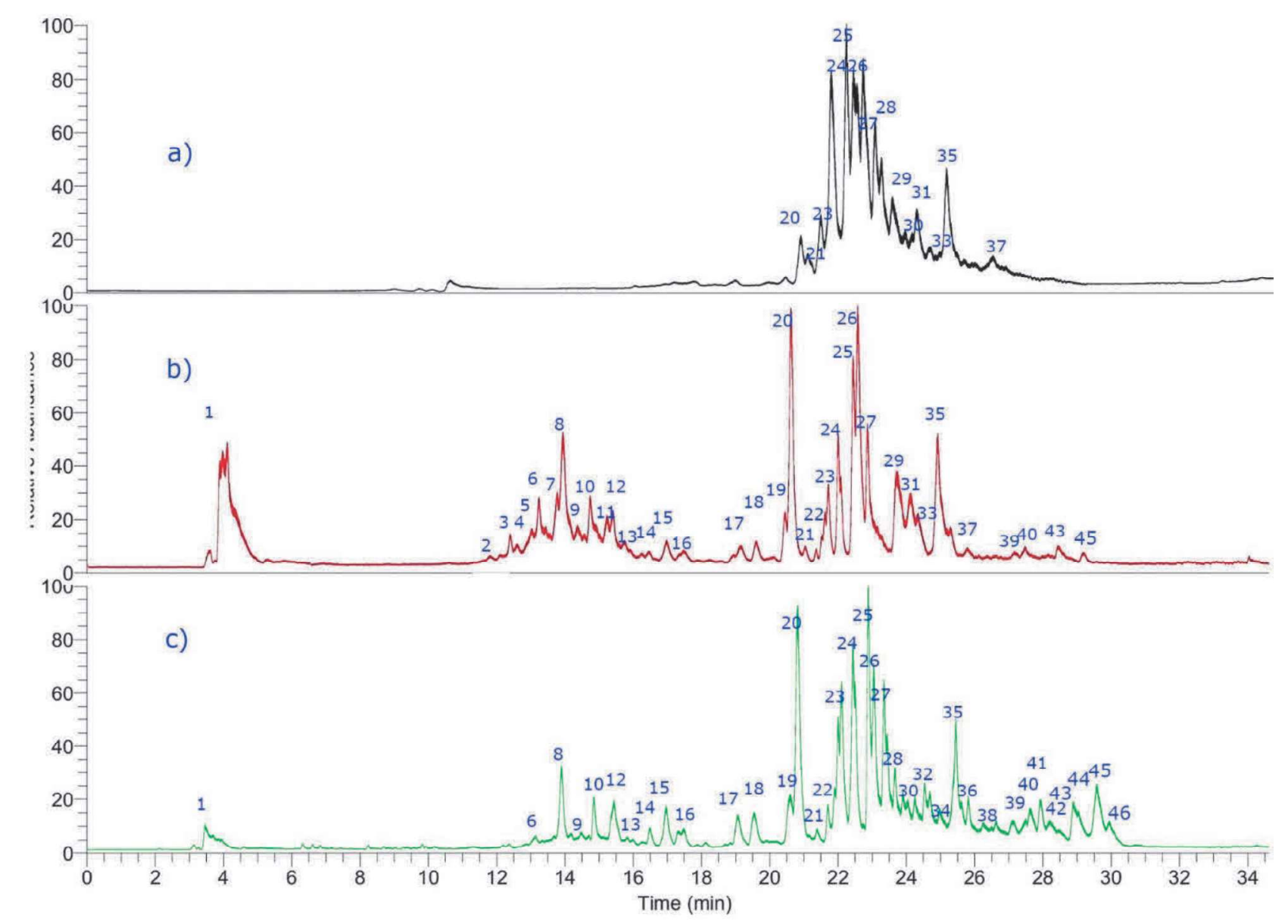

Fig. 5. High resolution UHPLC- MS chromatogram of Flourensia fiebrigii extract a) Ethanolic immersion, water soluble 


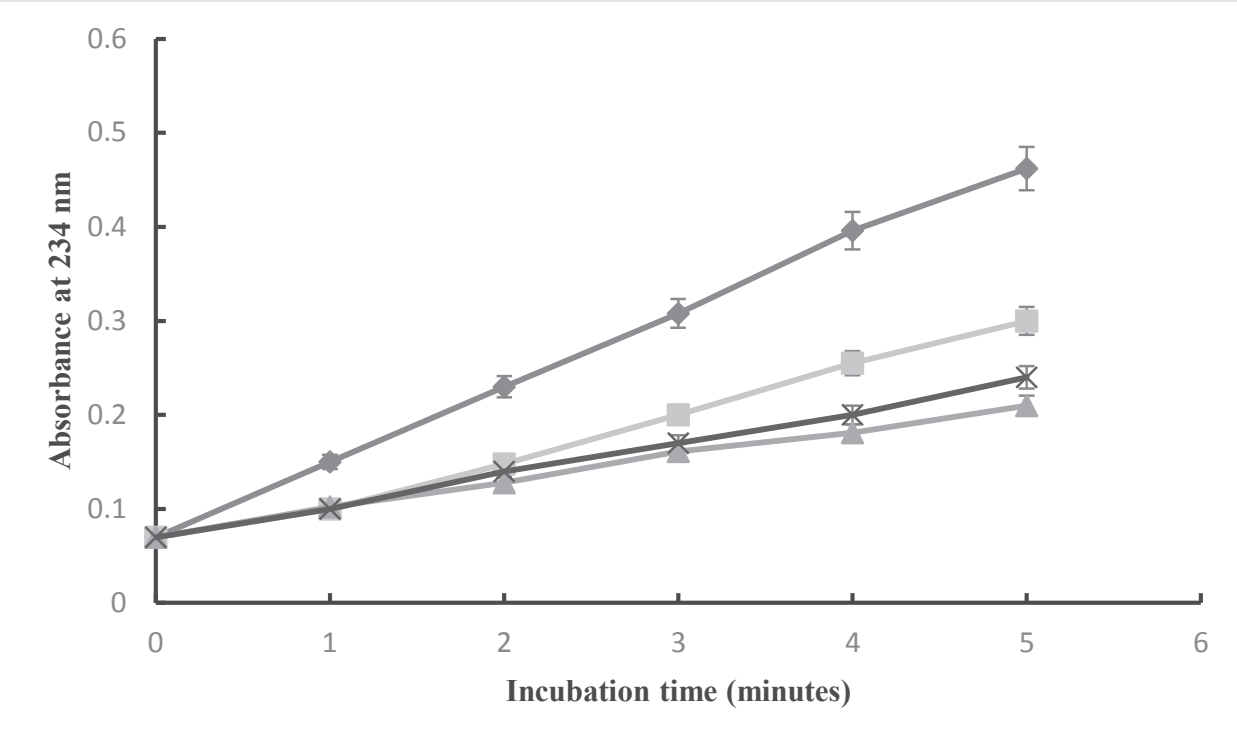

Fig. 6. (I) LOX activity in the absence $(\diamond)$ and presence of $F$. fiebrigii extracts: A) Ethanolic immersion, water soluble fraction

; B) Ethanolic immersion, ethanol soluble fraction - $\mathbf{\Delta}-$; C) Tincture $80^{\circ}$ ethanol $-\mathrm{X}-$.

\section{Acknowledgements}

This research was supported by grants from Consejo de Investigación de la Universidad Nacional de Tucumán (PIUNT 2018 G637 Project), Argentina, Agencia Nacional de Promoción Científica y Técnica (PICT 2014, 3136; Project, PICT 2017,4416

\section{References}

Amin, A, Chikan, N.A., Mokhdomi, T.A., Bukhari, S., Koul, A.M., Shah, B.A., Gharemirshamlu, F.R., Wafai, A.H., Qadri,

A, Qadri. R.A., 2016. Irigenin, a novel lead from Western Himalayan chemiome inhibits fibronectin-extra domain A induced metastasis in lung cancer cells. Sci. Rep. 6, 37151. 
Ariza Espinar, L., Ospina, J.C., 2015. Flourensia DC. Asteraceae: Cichorieae, Helenieae, Mutisieae. In F.O. Zuloaga, M.J. Belgrano and A.M Anton (eds.). Flora Vascular de la República Argentina 7(2), 20-212. Buenos Aires: Estudio Sigma S.R.L.

Beck, S. G., Ibáñez, D., 2014. Flourensia. - In: Jørgensen P.M. et al. (eds.), Catálogo de las Plantas Vasculares de Bolivia. Monogr. Syst. Bot. Miss. Bot. Gard. 127(1), 322-323.

Cabrera, A.L., 1978. Compositae: Flourensia. - In: Cabrera A.L. (ed), Flora de la Provincia de Jujuy, República Argentina, 13(10). Buenos Aires, Argentina: Colección Científica del INTA, pp. 361-366.

Calo, C, Pereyra-Domingorena, L., 2013. El ambiente y los recursos: un estudio sobre la recolección en La Quebrada (Catamarca, Argentina). Revista Española de Antropología Americana 43, 1, 133-154.

Cantero, J.C., Nuñez, C.O., Bernardello, G., Amuchastegui, A., Mulko, J., Brandolin, P., Palchetti, M.V., Iparraguirre, J., Virginil, N., Ariza Espinar, L., 2019. Las plantas de importancia económica en Argentina. First Edition. Ed. UniRío Editora. Universidad Nacional de Río Cuarto, pp. 937. https://botanicaargentina.org.ar/wp-content/uploads/2019/06/978-987-688332-0-baja-resoluci\%C3\%B3n.pdf (Last accessed, December 2019).

Catarino, M.D., Talhi, O., Rabahi, A., Silva, A.M.S., Cardoso, S.M., 2016. The antiinflammatory potential of flavonoids: Mechanistic aspects. Studies in Natural Products Chemistry Vol. 48. Chapter 3.

Choi, W., Villegas, V., Istre, H., Heppler, B., Gonzalez, N., Brusman, N., Snider, L., Hogle, E., Tucker, J., Oñate, A., Oñate, S., Ma, L., Paula, S., 2019. Synthesis and characterization of CAPE derivatives as xanthine oxidase inhibitors with radical scavenging properties. Bioorg. Chem. 86, 686-695.

Delbon, N., Cosa, M.T., Dottori, N., 2007. Anatomía de órganos vegetativos en Flourensia campestris y F. oolepis (Asteraceae), con especial referencia a las estructuras secretoras. Arnaldoa 14(1), 61-70.

Delbon, N., Cosa, M.T., Bernardello, G., 2012. Exomorfología y anatomía de órganos vegetativos aéreos en especies de Flourensia DC. (Asteraceae) con importancia fitoquímica. Acta Botanica Brasilica 26(1), 2-10.

Del Vitto, L., Petenatti, E., 2015. Asteráceas de importancia económica y ambiental. Segunda parte: Otras plantas útiles y nocivas. Multequina 24, 47-74.

Dillon, M.O.,1984. A systematic study of Flourensia (Asteraceae, Heliantheae). Fieldiana, Botany, New Series $16,1-67$.

Dilcher, D., 1974. Approaches to the identification of angiosperm leaves. Bot Rev. 40, 1-157. 
Dizeo de Strittmater, C., 1973. Nueva técnica de diafanización. Bol. Soc. Argent. Bot. 15, 126-129.

Ellis, B., Daly, D., Hickey, 1., Johnson, K., Mitchell, J., Wilf, P., Wing, S., 2009. Manual of leaf architecture. The New York Botanical Garden Press. New York.

Femenía, J. H., 2009. Flora del Famatina. Diario chilecito.com (inédito).

Funk, V.A., Susanna, A., Stuessy, T.F., Robinson, H.E., 2009. Classification of Compositae. In systematics, evolution, and biogeography of compositae. Funk, V.A., Susanna, A., Stuessy, T.F., Bayer, R.J. (Eds) International Association for Plant Taxonomy (IAPT). Vienna, Austria, pp. 171-189.

Garcia-Valladares, I., Khan, T., Espinoza, L.R., 2011. Efficacy and safety of febuxostat in patients with hyperuricemia and gout, Ther. Adv. Musculo skelet Dis. 3 (5), 245-253.

Gawlik-Dziki, U., Dziki D., Świeca M, Nowak R., 2017. Mechanism of action and interactions between xanthine oxidase inhibitors derived from natural sources of chlorogenic and ferulic acids. Food Chem. 15 (225), 138-145.

Göpfert, J.C., Heil, N., Conrad, J., Spring, O., 2005. Cytological development and sesquiterpene lactone secretion in capitate glandular trichomes of sunflower. Plant Biol. 7, 148-155.

Hadzich, A., Gross, G., Leimbach, M., Ispas, A., Bund, A., Flores, S., 2020. Characterization of Plukenetia volubilis L. fatty acid-based alkyd resins. Polym. Test. 106296.

Hickey, L., 1974. Clasificación de la arquitectura de las hojas de Dicotiledóneas. Bol. Soc. Argent. Bot. 16, 1-26.

Hickey, L., 1979. A revised classification of the architecture of dicotyledonous leaves. In: METCALFE, C. \& L. CHALK (eds.), Anatomy of the Dicotyledons. Vol. I. Second Edition, pp. 17-33 Clarendon Press, Oxford.

Hirai, S., Kim, Y., Goto, T., Kang, M., Yoshimura, M., Obata, A., Yu, R., Kawada, T., 2007. Inhibitory effect of naringenin chalcone on inflammatory changes in the interaction between adipocytes and macrophages. Life Sci. 81, 1272-1279.

Holdgate, G. A., Meek, T. D., Grimley, R. L., 2017. Mechanistic enzymology in drug discovery: a fresh perspective. Nat. Rev. Drug Discov. 17(2), 115-132.

Kim, H., Son, K., Chang, H., Kang, S., 2004. Anti-inflammatory plant flavonoids and cellular action mechanisms. J. Pharmacol. Sci. 96, 229-245.

Li, L., Zhou, G., Li, J., Jiang, W., Liu, B., Zhou, W., 2018. Compounds containing trace element copper or zinc exhibit as potent hyperuricemia inhibitors via xanthine oxidase inactivation. J. Trace Elem. Med. Bio. 49, 72-78. 
Lin, S., Zhang, G., Liao, Y., Pan, J., Gong, D., 2015. Dietary flavonoids as xanthine oxidase inhibitors: Structure-affinity and structure-activity relationships. J. Agric. Food Chem. 63, 35, 7784-7794.

López, D., Piazza, L., Silva, M., López Rivillia, M., Cantero, J., Tourn, G., Scopel, A., 2014. Distribution of (-)-Hamanasic acid A in South American species of Flourensia and phytotoxic effects of leaf aqueous extracts. Nat. Prod. Comm. 9, $341-345$

Mascayano, C., Nuñez, G., Acevedo, W., Rezende, M.C., 2010. Binding of arachidonic acid and two flavonoid inhibitors to human 12- and 15-lipoxygenases: a steered molecular dynamics study. J. Mol. Model. 16(5), 1039-1045.

Mercado, M.I., Coll Aráoz, M.V., Ruiz, A.I., Grau, A., Ponessa, G.I., 2012. Análisis estructural, ultraestructural y desarrollo ontogenético de los tricomas glandulares de Smallanthus sonchifolius (Asteraceae), Yacón. Lilloa 49 (1), 40-51.

Metcalfe, C.R., Chalk, L., 1950. Anatomy of the Dicotyledons: Leaves, Stem, and Wood in Relation to Taxonomy with Notes on Economic Uses. v.2. Claredon Press, Oxford.

Ospina, J.C., Aagesen, L., Ariza Espinar, L., Freire, S.E., 2018. Morphometric analyses and new taxonomic circumscription of South American species of Flourensia (Asteraceae, Heliantheae, Enceliinae). Nordic J. Bot. 36(6).

Panero, J.L., 2007. Compositae: tribu Heliantheae. In The families and genera of vascular plants, Volume 8: Flowering Plants: Eudicots -Asterales. Kadereit JW, Jeffrey C. (Eds) Springer - Verlag. Berlin, pp. 440-477.

Pereira, S. A. P., Dyson, P. J., Saraiva, M. L. M. F. S., 2020. Miniaturized technologies for high-throughput drug screening enzymatic assays and diagnostics - a review. TrAC Trends Analyt Chem, 115862.

Pérez, M.J., Zampini, I.C., Alberto, M.R., Isla, M.I., 2018. Prosopis nigra mesocarp fine flour, a source of phytochemicals with potential effect on enzymes linked to metabolic syndrome, oxidative stress, and inflammatory process. J.Food Sci 83(5), $1454-1462$.

Piazza, L.A., López, D., Silva, M.P., López Rivilli, M.J., Cantero, J.J., Tourna, G.M., Scopel, A.L., 2014. Characterization of quaternary ammonium compounds in Flourensia xerophytic communities and response to UV-B radiation. S. African J. Bot. 94, 14-23.

Reyes, M.G., Torres, M.J., Maggi, M.D., Marioli, J., Gil, R.R., Sosa. V., Uriburua, M.L., Audisio, M.C., 2013. inhibition of Paenibacillus larvae by different extracts and pure compounds from Flourensia spp. Ind. Crop Prod. 50, 758763. 
Ribeiro, D., Freitas, M., Tome, S.M., Silva, A.M.S., Porto, G., Cabrita, E.J., Marques, M.M.B., $\quad$ Fernandes, E., 2014. Inhibition of LOX by flavonoids: a structure-activity relationship study. Eur. J. Med. Chem. 72, 137-145.

Robinson, H., 1981. A revision of the tribal and subtribal limits of the Heliantheae (Asteraceae). Smithsonian Contr. Bot. 51, $1-102$.

Singleton, V.L., Orthofer, R., Lamuela-Raventos, R.M., 1999. Analysis of total phenols and other oxidation substrates and antioxidants by means of Folin-Ciocalteu reagent. Methods Enzymol. 299, 152-178.

Shengban, Y., Jianchang, Q., Gaojun, W., Yuanyuan, Q., Zhengxian,W., Taiwei, C., Jingying, W., $\quad$ Weijian, H., Guang, L., 2019. Schizandrin B attenuates angiotensin II induced endothelial to mesenchymal transition in vascular endothelium by suppressing NF-kB activation. Phytomedicine 62, 152955.

Sinha, S., Doble, M., Manjua, S.L., 2019. 5-Lipoxygenase as a drug target: A review on trends in inhibitors structural design, SAR and mechanism based approach. Bioorgan. Med. Chem. 27, 3745-3759.

Silva, M.P., Tourn, G.M., López, D., Galati, B.G., Piazza, L.A., Zarlavsky, G., Cantero, J.J., Scopel, A.L., 2015. Secretory structures in Flourensia campestris and F. oolepis: Ultrastructure, distribution, and (-)-Hamanasic acid A secretion. Am. J. Plant Sci. 6, 925-942.

Simirgiotis, M.J., Quispe, C., Bórquez, J., Schmeda-Hirschmann, G., Avendaño, M., Sepúlveda, B., Winterhalter, P., 2016. Fast high resolution Orbitrap MS fingerprinting of the resin of Heliotropium taltalense Phil. from the Atacama Desert. Ind. Crop Prod. 85, 159-166.

Stuessy, T.F., 1977. Heliantheae-systematic review. In: Heywood V. H. et al. (eds.). The biology and chemistry of the Compositae. II. Turner Academic, London, pp. 621-697.

The Plant List (2013). Version 1.1. http://www.theplantlist.org/ (accessed 01.01.2020).

Torres-Carro, R., Isla, M.I., Thomas-Valdes, S., Jiménez-Aspee, F., Schmeda-Hirschman, G., Alberto, M.R., 2017. Inhibition of pro-inflammatory enzymes by medicinal plants from the Argentinean highlands (Puna). J. Ethnopharm. 205, 57-68.

Uriburu, M.L., Gil, R.R., Sosa, V.E., de la Fuente, J.R., 2007. Prenylflavonoids from Flourensia fiebrigii. Phytochem. 68, $1295-1299$.

Vázquez-Agell, M., Sacanella, E., Tobias, E., Monagas, M., Antúnez, E., Zamora-Ros, R., Andres-Lacueva, C., LamuelaRaventós, R.M., Fernández-Solá, J., Nicolas, J.M., Estruch, R., 2007. Inflammatory markers of atherosclerosis are 

2284.

513 Verni, C., Alva, M., Muruaga, N., Borkosky, S., Cartagena, E., Bardón, A., 2011. Flourensia fiebrigii (Asterales: Asteraceae), fuente de metabolitos antipatogénicos. Lilloa 48 (1), 91-99.

Wang, G., Zou, G., You, X., Zhang, Y., Jiang, H., Li, F., Li, G., 2017. Tectorigenin and irigenin inhibit lipopolysaccharideinduced nitric oxide synthase expression in murine macrophages. Biomed. Res. 28. xanthine oxidase. J. Agric. Food Chem. 63, 526-534.

Woisky, R.G., Salatino, A., 1998. Analysis of propolis: some parameters and procedures for chemical quality control. J. Apic. Res. 37 (2), 99-105.

521 Yadav, V., Prasad, S., Sung, B., Aggarwal, B., 2011. The role of chalcones in suppression of NF- $\kappa$ B-mediated inflammation and cancer. Inter. Immunopharmacol. 11, 295-309. 